\title{
Refusal Strategies of Iranian University English as a Foreign Language and Non-English Learners in Native Language: A Comparative Study
}

Seyyed Hatam Tamimi SA'D ${ }^{\star 1}$ And Zohre QAdermazI ${ }^{2}$

$\approx \quad$ This study is an attempt to examine the possible effect that exposure to English has had on the use of refusal strategies in English as a Foreign Language (EFL) learners compared with those of non-English learners when refusing in their native language, Persian. The sample included 12 EFL learners and 12 learners of other academic majors including electronics, psychology, management, etc., who responded to a Persian Discourse Completion Task (DCT), adopted from Allami and Naeimi (2011), who has engaged in the speech act of refusal. The responses were coded according to the classification of refusal strategies as outlined by Beebe, Tahakashi and Uliss-Weltz (1990). The results indicated that non-English learners used the refusal strategies considerably more frequently than the EFL learners did, while the EFL learners utilized more adjuncts to refusals than the non-English learners did. However, the differences were not statistically significant. Furthermore, the first four most frequently used refusal strategies by both EFL and non-English groups were found to be "Non-performative statement" (in the case of direct strategies and in the form of "I can't"), "Statement of regret", "Excuse, reason or explanation" and "Attempt to dissuade interlocutor" (in the case of indirect strategies), and the most frequently used adjuncts to refusal strategies by both EFL and non-English groups were "Statement of positive opinions, feelings or agreement" and "Gratitude/Appreciation". Furthermore, gender differences were not statistically significant either. The results can be evidence that the effect of the second language (L2) on the native language (L1) might not be at work in the pragmatic aspects of language learning.

Keywords: Refusal, Refusal Strategies, Speech Acts, English as a Foreign Language (EFL) Learners, Non-English Learners; Politeness

$1 \quad{ }^{\star}$ Corresponding Author. Urmia University, Iran; shtamimi9o@gmail.com

2 Urmia University, Iran 


\section{Odklonilne strategije iranskih univerzitetnih študentov anglistike in študentov neanglistov $\mathrm{v}$ domačem jeziku: primerjalna študija}

Seyyed Hatam Tamimi SA'D ${ }^{*}$ in Zohre Qadermazi

$\approx$ V študiji skušamo preveriti mogoče učinke izpostavljenosti angleščini na uporabo odklonilnih strategij študentov anglistov v primerjavi s tistimi, ki jih imajo študentje neanglisti, ko jih odklanjajo v svojem domačem jeziku, perzijščini. V vzorec je bilo zajetih 12 študentov anglistike in 12 študentov drugih predmetnih smeri, kot so: elektronika, psihologija, uprava itn., ki so izpolnili diskurzno nalogo dopolnjevanja (ang. Discourse completion task), prirejeno po Allami in Naeimi (2011), ki sta se ukvarjala z govornim dejanjem odklanjanja. Za kodiranje odzivov vključenih študentov so uporabili klasifikacijo odklonilnih strategij Beebeja, Tahakashija in Uliss - Weltzove (1990). Rezultati kažejo, da so študentje neanglisti precej pogosteje uporabljali odklonilne strategije kot študentje anglistike, medtem ko so se ti posluževali večjega števila pristavkov odklanjanja kot študentje neanglisti. A razlike niso bile statistično pomembne. Štiri najpogosteje uporabljene odklonilne strategije anglistov in neanglistov so vključevale: "neperformativne izjave (pri direktnih strategijah oziroma pri odgovorih »I can’t.«), »izjave obžalovanja«, "opravičila, navajanja razlogov ali razlaganja « in "poskuse prepričevanja sogovornika ( pri indirektnih strategijah). Pristavki odklanjanja, ki so jih študentje anglistike in tudi študentje neanglisti uporabljali v največji meri, so se nanašali na »izjave pozitivnega mnenja, občutij in strinjanja« ter »zahvale/upoštevanja«. Tudi razlike med spoloma niso bile statistično pomembne. Rezultate lahko razumemo kot ugotovitev, da pri pragmatičnih vidikih jezikovnega procesiranja, tuj jezik ne učinkuje na domači jezik.

Ključne besede: odklanjanje, odklonilne strategije, govorno dejanje, študentje anglistike, študentje neanglisti, vljudnosti 


\section{Introduction}

The issue of second language (L2) learners' pragmatic competence has long been the subject of heated discussion in language teaching. Moreover, refusing can be a very challenging task to perform even in one's native language (L1) (Al-Kahtani, 2005). Refusing in an appropriate way is taken to be evidence of pragmatic competence since the speech act of refusal is an extremely facethreatening act (FTA) which is most likely to damage the addressee's face very easily (Brown \& Levinson, 1987). For decades, the prevalent idea has been that the pragmatic norms of the L1, which are learned during childhood, affect the learning process and product of the L2. However, it has also been assumed that this transfer from the $\mathrm{L}_{1}$ to the $\mathrm{L}_{2}$ can also be from the $\mathrm{L}_{2}$ to the $\mathrm{L} 1$, a phenomenon that has been mostly documented in the learning of vocabulary (Ellis, 2012). This study assumes that there is the possibility that the norms of the L2 might turn to be at work when using one's L1 in producing different speech acts. Table 1 offers the refusal strategies, consisting of Direct Refusals, Indirect Refusals and Adjuncts to Refusals, as classified by Beebe et al. (1990, as cited in Farnia \& Wu, 2012, p. 174).

Table 1. Classification of Refusal Strategies

\begin{tabular}{lll}
\hline Type & Strategies & Semantic Formulas \\
\hline I) Direct & A) Performative & I refuse \\
B) Non-performative statement & \\
1. "No" & \\
2. Negative willingness/ability & I can't; I won't; I don't think so. \\
\hline II) Indirect & A) Statement of regret & I'm sorry; I feel terrible. \\
& B) Wish & I wish I could help you. \\
C) Excuse, reason, explanation & I have a headache. \\
D) Statement of alternative & \\
1. I can do X instead of Y & I'd rather do...; I'd prefer \\
2. Why don't you do X instead of Y & Why don't you ask someone else \\
E) Set condition for future or past & If you had asked me earlier, I would \\
acceptance & have... \\
F) Promise of future acceptance & I'll do it next time; I promise \\
I'll..; - Using "will" of promise or & "promise" \\
G) Statement of principle & I never do business with friends. \\
H) Statement of philosophy & One can't be too careful.
\end{tabular}


I) Attempt to dissuade interlocutor

1. Threat or statement of negative consequences to the requester

2. Guilt trip

3. Criticize the request/requester, etc. (statement of negative feeling or opinion); insult/attack

4. Request for help, empathy, and assistance by dropping or holding the request.

5. Let interlocutor off the hook

6. Self-defence

J) Acceptance that functions as a refusal

1. Unspecific or indefinite reply

2. Lack of enthusiasm

K) Avoidance

1. Nonverbal
a. Silence
b. Hesitation
C. Do nothing
d. Physical departure

2. Verbal
a. Topic switch
b. Joke
c. Repetition of part of request, etc.
d. Postponement
e. Hedging

Adjuncts to refusals
"I won't be any fun tonight" to refuse an invitation

Waitress to customers who want to sit a while: "I can't make a living off people who just order coffee."

Who do you think you are?; That's a terrible idea!

Don't worry about it; That's okay; You don't have to.

I'm trying my best; I'm doing all I can.
Monday?

I'll think about it.

Gee, I don't know; l'm not sure.
1. Statement of positive opinions/
That's a good idea...; l'd love to... feeling or agreement
2. Statement of empathy
I realize you are in a difficult situ- ation.
3. Pause filler
uhh; well; uhm.
4. Gratitude/appreciation

By comparing the refusal strategies and adjuncts to refusal strategies of English as a Foreign Language (EFL) and non-English learners in their first language, Persian, this study aims to throw light on the bidirectional influence, 
if any, that exposure to English has had on EFL learners' pragmatic competence. The study is, therefore, comparative, attempting to gauge the possible effect that exposure to an L2 (here, English) has on one's L1 (here, Persian). More specifically, the study addressed the following research questions:

1. What are the types and frequencies of the refusal strategies and adjuncts to refusals that Iranian EFL and non-English learners use when refusing in their L1, Persian?

2. Is there any significant difference between EFL and non-English learners in their use of refusal strategies and adjuncts to refusals in Persian?

3. Is there any significant difference between EFL and non-English males and females in their use of refusal strategies and adjuncts to refusals in Persian?

4. Does the exposure to English have any effect on EFL learners' the use of refusal strategies and adjuncts to refusals in Persian?

\section{Theoretical framework}

Research into L2 production of speech acts in general and refusals in particular has been increasingly rigorous (Al-Kahtani, 2005; Allami \& Naeimi, 2011; Beebe et al., 199o; Farnia \& Wu, 2012; Ghazanfari, Bonyadi, \& Malekzadeh, 2013; Hassani, Mardani, \& Dastjerdi, 2011; Lingli \& Wannaruk, 2010; MartínezFlor \& Usó-Juan, 2011; Silva, 2003; Umale, 2011; Yang, 2008). This research has been mainly motivated by the fact that refusing a suggestion, invitation or offer by nature leads to disruption in harmony in relationships and, as a consequence, performing this speech act has to be carried out very carefully. The line of research has focused on various issues surrounding this speech act, such as a comparison of native and non-native speakers' refusal strategies (Umale, 2011), the effect of instruction on the language learners' refusals (Lingli \& Wannaruk, 2010), and so forth. Umale (2011) carried out a study to investigate the similarities and differences between ten British speakers and ten Omanis who responded to situations in a Discourse Completion Task (DCT) that consisted of various interlocutor statuses (low, high and equal). Umale's findings suggested that both the Omanis and the British speakers tended to use indirect refusal strategies, mainly statement of regret, care for the interlocutor's feeling, giving reasons and promise for future acceptance, to refuse requests from their superiors. Umale concluded that while Omanis tried to sound polite when refusing, their overly long answers often led to pragmalinguistic failure.

The role of implicit and explicit instruction in English refusals of 62 Chinese learners of English was examined by Lingli and Wannaruk (2010). They 
found that while no significant difference was observed with regard to refusals to offers and suggestions, the explicit instruction was better than implicit instruction in refusals to invitations and requests. In general, they concluded that the explicit teaching in English of refusals was found to be better than implicit instruction. The effect of explicit instruction on the development of polite refusal strategies was also the subject of investigation in another study (Silva, 2003). The study incorporated task-based principles into the teaching of the sociopragmatic as well as the pragmalinguistic aspects of refusals. The findings revealed that the subjects in the experimental group, a sample of 14 lowintermediate learners of English, made considerable pragmatic development compared to those in the control group. For instance, some refusal strategies that were absent in the pre-test appeared in the post-test phase which resulted in more polite refusals. Yang (2008) conducted a study of refusal strategies that was aimed at discerning the motivating acts that prompted the refusals to be made. The data gathered from clips taken from five Chinese TV series shown throughout China indicated that refusals were most often prompted by requests, offers, invitations and suggestions; specifically, the individuals refused those acts that were requests, invitations, offers or suggestions but rarely ever refused other acts.

Researchers have also focused on the instrumentation phase of interlanguage research. Martínez-Flor and Usó-Juan (2011) examined the appropriate data collection tools for gathering data on refusals to requests, comparing oral role plays, written discourse completion tasks and awareness tests and their effect on the production and comprehension of refusals among university students. They concluded their study with the comment that these tasks can be utilized not only to collect data on pragmatics-related aspects of language learning, but also to teach these aspects to L2 or FL learners. In a very recent study, Ghazanfari et al. (2013, p. 60) examined the realizations of the refusal strategies by Persian and English native speakers in 100 films. They found that there were differences in these realizations that may lead to breakdowns in communication, particularly concerning the fact that "English speakers are more direct, more open in their interactions, and more straightforward, using performative verbs and non-performative statements more than Persian speakers". AlKahtani (2005) took into account the way refusal strategies are realized in three different cultures (American, Arab and Japanese) but in the same language, English. Al-Kahtani's study of these three cultural groups showed that although refusals were realized differently in different cultures, there were similarities in the way that requests were refused by the groups. He determined that regret, excuse, reason, and explanation were the most frequent refusal strategies used. 
He recommended that teachers teach the appropriate use of refusal strategies so that EFL learners avoid breakdowns in cross-cultural communication. In a study of Chinese and Malaysian university students' refusal behavior, Farnia and $\mathrm{Wu}$ (2012) investigated the refusals to invitation by use of a written discourse completion test and an immediate structured interview aimed to examine their perception concerning their cognition and language of thought in the process of refusing. The findings showed that both groups used similar types of refusal strategies, but they differed in the frequency of the refusals. In addition, the most frequent refusal strategies were found to be statements of regret, excuses, reasons and explanation and expression of negative ability and willingness.

About the adjuncts to refusals, the results also revealed that the participants used positive opinions, feelings, or agreement, expressions of gratitude and appreciation and alerters the most frequently. Hassani et al. (2011) focused on the role of gender and social status in their cross-linguistic study of the refusal strategies of a group of 60 EFL learners who responded to a DCT with a time interval in between. The results showed no significant difference as regards the role of gender, and the higher social status was found to result in the learners' use of indirect refusal strategies in Persian while more direct strategies were used in English. Allami and Naeimi (2011) focused on the pragmatic development of Iranian EFL learners in their cross-linguistic study in which they examined the frequency, shift and content of semantic formulae of the refusals of three groups of Persian speakers, Persian learners of English and native speakers of English, taking into account the learners' language proficiency, status of interlocutors and types of eliciting acts. The findings indicated that differences in the shift, frequency and semantic formulae of the native and nonnative speakers and that the most frequently used refusal strategies were direct refusals, statements of regret and excuse, reason and explanation. Allami and Naeimi noted that Iranian EFL learners demonstrated evidence of pragmatic transfer of the sociocultural norms from their L1 (Persian) to L2 (English).

It can be seen that most studies have examined refusal strategies across two languages or cultures and rarely have researchers attempted to investigate refusal behaviour across disciplines. Therefore, what seems to be missing from the line of research on refusals is a comparative study of refusal strategies as used by EFL and non-English learners in their L1 as an examination of the possible effect of exposure to an L2 on L1. This study set out to examine this issue, aiming at presenting a fuller picture of bidirectional transfer of L2 pragmatic norms to L1 situations. 


\section{Methodology}

\section{Participants}

The participants consisted of 12 MA non-English learners, (6 males and 6 females), majoring in electronics, veterinary medicine, food industries, economics, management, etc. and 12 MA EFL learners (6 males and 6 females). The age range of the EFL group was within 23 to 28 years and the non-English within 18 to 28 years. Regarding the participants' linguistic background, they spoke Persian as their mother tongue. It is noteworthy that by the term "Non-English Learners" are meant those learners who studied majors other than English (as previously mentioned) and that EFL learners are those majoring in different majors of English, such as translation, English literature and English language teaching.

\section{Instruments}

Research data were collected by use of a written Discourse Completion Task (DCT) that was adopted from Allami and Naeimi's (2011) study of refusal strategies. This DCT consists of 12 situations, two of which deal with academic settings and the others with everyday life, i.e. a variety of situations. Allami and Naeimi used two DCTs in their study, one Persian and the other English. For the purposes of the current study, however, only the Persian version was utilized. In addition, the purpose of the study was to see how the EFL group and the non-English group differed in their use of refusal strategies in Persian, the learners' native language, to examine if the exposure to English in EFL learners has affected their use of refusal strategies in Persian; specifically, the objective of the study was to investigate the effect of the exposure to L2 one one's L1 use. The DCT appears in Appendix A.

\section{Procedure and Data Analysis}

The data were collected through a Persian DCT that was completed by the participants studying English or other majors in Urmia University, Iran. The reliability and validity of the DCT had been already established in Allami and Naeimi's (2011) study. However, the DCT was checked by two experts in the field for content and face validity. The data were analyzed and coded based on the taxonomy of refusals as developed by Beebe et al. (1990). Following the lead of Allami and Naeimi's (2011) study, the semantic formulas were utilized as units of analysis. This taxonomy identifies two direct and eleven indirect refusal strategies together with four adjuncts to refusals including expression of positive feeling, agreement, pause fillers, among others as mentioned in Table 1 . Since the coding of the data according to the aforementioned taxonomy 
included an inevitable degree of subjectivity on the part of the coder, another coder, who was an expert in the field, coded the refusal utterances of the subjects of the study, according to the afore-mentioned taxonomy. The inter-coder reliability was found to be $82 \%$, which was considered sufficient to allow the data analysis process to proceed. Descriptive statistics, such as percentages and frequency counts, were also offered to shed further light on the use of refusal strategies by both groups. Furthermore, using the SPSS software, the Chisquare test was conducted to see if there is any significant difference between the two participant groups and between males and females in each group. The data were also examined qualitatively, and examples of the participants' refusal utterances were presented for a better picture of the use of refusal strategies among the EFL and non-English groups.

\section{Results}

This study aimed at investigating the possible differences between EFL and non-English learners in the use of refusal strategies in to examine if exposure to English has had impacted on the use of such strategies in EFL learners. Table 2 below summarizes the overall use of refusal strategies by both groups of EFL and non-English learners.

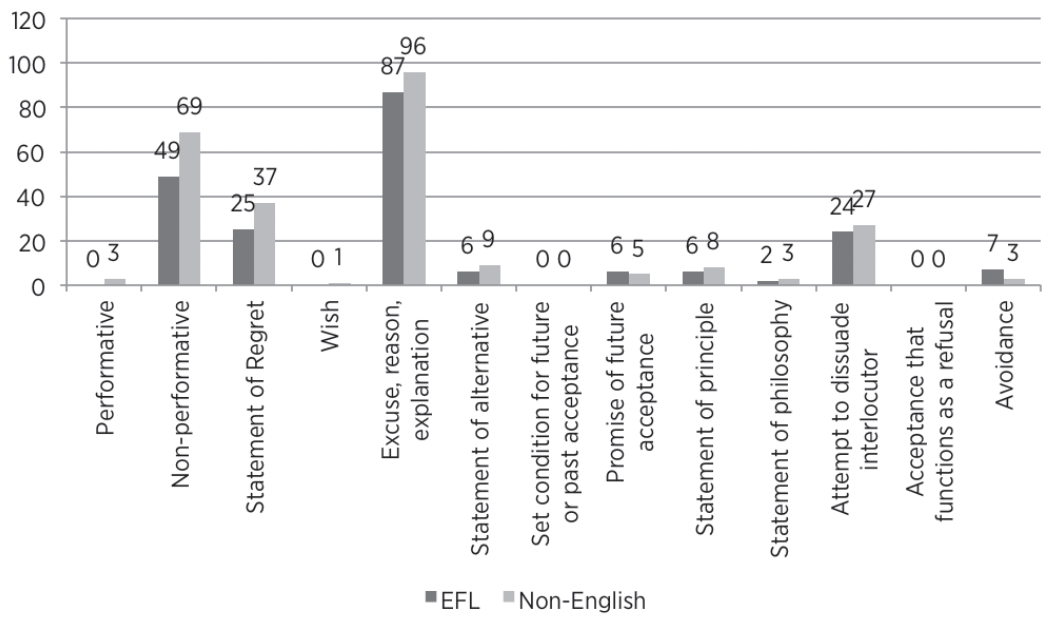

Figure 1. Refusal Strategy Use across Participant Groups

Figure 1 shows that the EFL group used the refusal strategies 212 times and the non-English group 262 times. Figure 1 also indicates that the most 
frequent direct refusal strategy as used by both groups is the "Non-performative statement". The "Performative" refusal strategy, which is realized mainly through "I refuse", however, was not used by the EFL group but by the nonEnglish group. In addition, it is seen that the non-English group has used the "Non-performative statement" more frequently than the EFL group (69 versus 49 ). In the case of indirect refusal strategies, the first three most frequent refusal strategies for both groups are: 1) Excuse, reason, explanation, 2) Statement of regret and 3) Attempt to dissuade interlocutor. This figure also shows that both groups have employed other refusal strategies with similar frequencies. The three least frequently used refusal strategies are: 1) Wish, 2 Statement of philosophy and 3) Avoidance. Two refusal strategies were not used by either group at all: "Set condition" and "Acceptance".

The study investigated the role of gender in the use of refusal strategies as well. The results of refusal strategy use across the gender of the participants of both EFL and non-English groups are presented in Table 2.

Table 2. Refusal Strategy Use across Participant Groups and Gender

\begin{tabular}{|c|c|c|c|c|c|c|}
\hline \multirow{3}{*}{ Refusal strategy } & \multicolumn{4}{|c|}{ Group } & \multirow{2}{*}{\multicolumn{2}{|c|}{ Total }} \\
\hline & \multicolumn{2}{|c|}{ EFL } & \multicolumn{2}{|c|}{ Non-English } & & \\
\hline & M & $\mathrm{F}$ & M & $\mathrm{F}$ & Freq & $\%$ \\
\hline \multicolumn{7}{|l|}{ I. Direct } \\
\hline Performative & 0 & 0 & 1 & 2 & 3 & 0.6 \\
\hline Non-performative & 26 & 23 & 24 & 45 & 118 & 24.9 \\
\hline \multicolumn{7}{|l|}{ II. Indirect } \\
\hline Statement of Regret & 17 & 8 & 12 & 25 & 62 & 13.1 \\
\hline Wish & 0 & 0 & 1 & 0 & 1 & 0.2 \\
\hline Excuse, reason, explanation & 39 & 48 & 45 & 51 & 183 & 38.6 \\
\hline Statement of alternative & 1 & 5 & 0 & 9 & 15 & 3.2 \\
\hline Set condition for future or past acceptance & 0 & 0 & 0 & 0 & 0 & 0 \\
\hline Promise of future acceptance & 3 & 3 & 4 & 1 & 11 & 2.3 \\
\hline Statement of principle & 3 & 3 & 4 & 4 & 14 & 3 \\
\hline Statement of philosophy & 2 & 0 & 2 & 1 & 5 & 1.1 \\
\hline Attempt to dissuade interlocutor & 14 & 10 & 11 & 16 & 51 & 10.8 \\
\hline Acceptance that functions as a refusal & 0 & 0 & 0 & 1 & 1 & 0.2 \\
\hline Avoidance & 6 & 1 & 2 & 1 & 10 & 2.1 \\
\hline Total & 111 & 101 & 106 & 156 & 474 & 100 \\
\hline
\end{tabular}

Note. M=Male; F=Female; Freq=Frequency. 
According to Table 2, the males in both the EFL and non-English groups do not differ considerably in the number of the strategies they have used in refusing (111 versus 106). However, females of the non-English group used a relatively higher number of refusal strategies than the females in the EFL group (156 versus 101). For both genders of both groups, the most frequently used refusal strategies are 1) Non-performative, 2) Statement of Regret and 3) Excuse, reason, explanation. It is also seen that the EFL females used the strategy of "Statement of Regret" far less frequently than the non-English females (8 versus 25). No considerable differences are observed between the two genders of both groups in almost all other refusal strategies, except in the strategy of "Nonperformative" which the non-English females have used much more frequently than the EFL females (45 versus 23).

The differences between the genders of the two groups were also investigated statistically in Table 3 by means of a Chi-square test.

Table 3. Chi-square Analysis of Refusal Strategy Use by EFL and Non-English Groups

\begin{tabular}{llll}
\hline & Value & Df & Sig. \\
\hline Chi-square & 8.933 & 11 & .628 \\
\hline$p<.05$ & Critical Value: 19.675 & &
\end{tabular}

Table 3 shows that the two groups of EFL and non-English learners did not differ significantly in their use of refusal strategies, $\mathrm{X}^{2}(11,474)=8.933$, $p=.628$.

One important aspect of the speech act of refusing is the level of directness with which a refusal strategy can be encoded. This level of directness, that is, the use of direct versus indirect refusal strategies, was also examined across the two participant groups in Figure 2. 


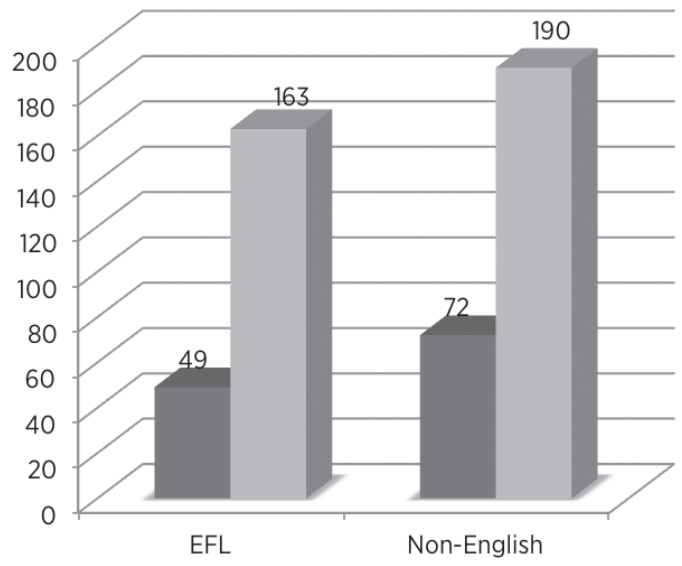

- Direct Refusal Strategies

"Indirect Refusal Strategies

Figure 2. Level of Directness of Refusal Strategies of Participant Groups

Figure 2 shows that Direct and Indirect refusal strategies constitute $23.1 \%$ (49) and $76.8 \%$ (163) of the refusal strategies used by the EFL group, respectively. The non-English group relied on these in $27.4 \%(72)$ and $72.5 \%$ (190) of the time. The differences between the groups are not, therefore, considerable. However, a Chi-square test was run to investigate this difference more deeply. Table 4 summarises the results in this regard.

Table 4. Chi-square Analysis of the Directness of EFL and Non-English Groups' Refusal Strategies

\begin{tabular}{llll}
\hline & Value & df & Sig. \\
\hline Chi-square & 1.176 & 1 & .278 \\
\hline
\end{tabular}

$p<.05$ Critical Value: 3.841

As can be seen from Table 4, the results of this analysis indicated that there was no significant difference between the two groups in their use of direct and indirect refusal strategies, $\mathrm{X}^{2}(1,474)=1.176, \mathrm{p}=.278$.

Apart from the level of directness, another significant aspect of the refusal behaviour is the use of adjuncts $t$ refusals, defined earlier. This aspect was examined across both participant groups, and the results are presented in Figure 3 . 


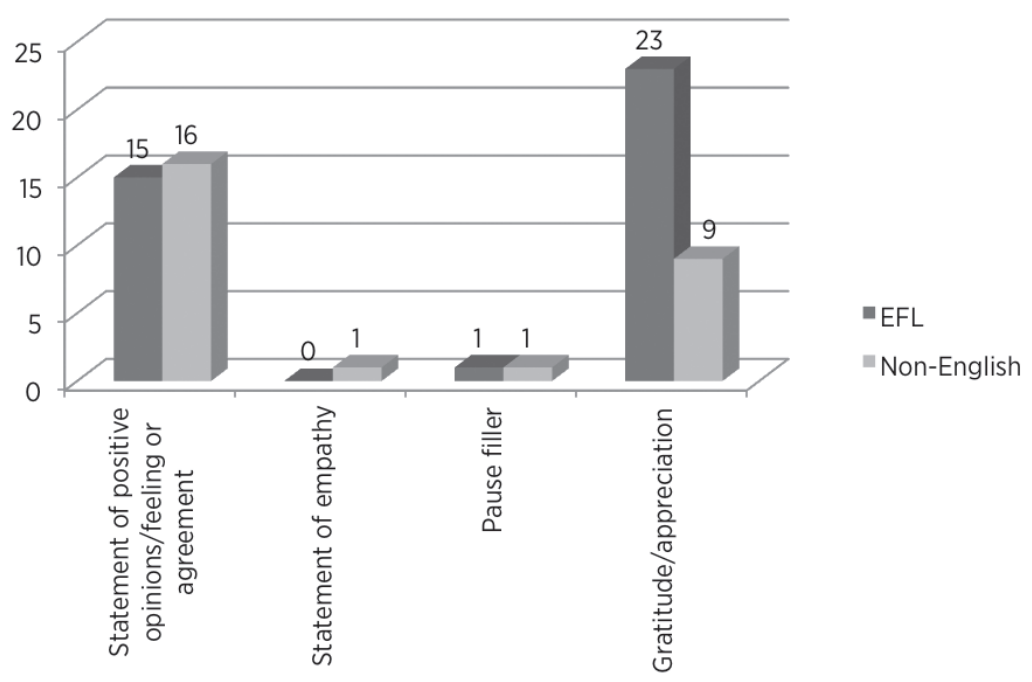

Figure 3. Adjunct to Refusal Strategy Use across Participant Groups

Figure 3 shows that overall the EFL group has used the adjuncts more frequently than the non-English group (39 versus 27). As can be seen, all the adjuncts have been used with nearly the same frequency except for the adjunct of "Gratitude/Appreciation" which has been used much more frequently by the EFL group than the non-English group (23 versus 9). This aspect of refusal behaviour was also examined with gender in focus in Table 5 below.

Table 5. Adjunct to Refusal Strategy Use across Participant Groups and Gender

\begin{tabular}{|c|c|c|c|c|c|c|}
\hline \multirow{3}{*}{ Adjunct } & \multicolumn{4}{|c|}{ Group } & \multirow{2}{*}{\multicolumn{2}{|c|}{ Total }} \\
\hline & \multicolumn{2}{|c|}{ EFL } & \multicolumn{2}{|c|}{ Non-English } & & \\
\hline & M & $\mathrm{F}$ & M & $\mathrm{F}$ & Frequency & $\%$ \\
\hline Statement of positive opinions/feeling or agreement & 8 & 7 & 9 & 7 & 31 & 46.9 \\
\hline Statement of empathy & 0 & 0 & 0 & 1 & 1 & 1.5 \\
\hline Pause filler & 1 & 0 & 0 & 1 & 2 & 3 \\
\hline Gratitude/appreciation & 11 & 12 & 5 & 4 & 32 & 48.4 \\
\hline Total & 20 & 19 & 14 & 13 & 66 & 100 \\
\hline
\end{tabular}

Note. $\mathrm{M}=$ Male; $\mathrm{F}=$ Female.

Table 5 indicates that both the EFL males and females used these adjuncts more frequently than the non-English males and females. The most considerable difference is seen in the case of "Gratitude/Appreciation" where 
the EFL males and females used this adjunct much more than the non-English group (23 versus 9). The role of gender in the use of adjuncts to refusals was also investigated statistically. Table 6 presents the results of a Chi-square test run to determine if there is any statistically significant difference between the two groups in their use of adjuncts to refusals.

Table 6. Chi-square Analysis of Adjunct to Refusal Strategy Use by EFL and Non-English Groups

\begin{tabular}{llll}
\hline & Value & df & Sig. \\
\hline Chi-square & 5.146 & 3 & .161 \\
\hline$p<.05 \quad$ Critical Value: 7.815 & &
\end{tabular}

According to Table 6, the results of this analysis indicated that there was no significant difference between the two groups in their use of adjuncts to refusal strategies, $\mathrm{X}^{2}(3,66)=5.146, \mathrm{p}=.161$.

\section{Discussion}

A comparison of the results of the refusal strategy and adjunct to refusal strategy use among the EFL and non-English learners of the present study with the results obtained in other studies demonstrates a considerable level of consistency between the present and previous studies. For instance, similar results were reported in Nelson, Al Batal and El Bakary (2002), Wannaruk (2008), Allami and Naeimi (2011), Abdul Sattar et al. (2011), Umale (2011) and Farnia and $\mathrm{Wu}$ (2012), among others. It seems that a similar pattern of refusing is followed by L2 learners in various cultures and languages as various studies have demonstrated. These studies were conducted with speakers from various languages including Arabic, English and Persian but the results of the majority of them indicate that similar patterns of refusing are followed by the interlocutors. This study, for example, showed whether EFL learners or non-English learners made extensive use of explanation, stated regret and expressed inability or unwillingness to refuse an invitation, a request or an offer. These three strategies are exemplified in bold in the following refusal utterances (the examples are in Persian, below which their English translation is presented):

- Man sharmandam. Khodam hanooz nakhundamesh.

- I'm sorry. I myself haven't studied them yet. (Regret \& Excuse; Sit \#2; female EFL learner) 
- Vaghean sharmande. Vali khune tamas gereftan ye kari pish oomade. Bebakhshid.

- I'm so sorry. But they called me and there's something I should do at home. Excuse me. (Regret+Excuse+Apology; Sit \#6; male non-English learner)

- $\quad$ Bikhial, mohem nist.

- $\quad$ Forget about it, that's no important. (Attempt to dissuade; Sit \#7; male non-English learner)

The extensive use of "Excuse, reason and explanation" as a refusal strategy by both EFL and non-English groups is remarkably in line with Allami and Naeimi's (2011) findings in that the Iranian participants of this study who responded to the DCT in Persian used this strategy most frequently of all other strategies. The common use of this strategy seems to be justifiable on the grounds that giving explanations and excuses might be the most immediate strategy that comes in handy in almost every situation.

Regarding the adjuncts to refusals, the results also revealed that the participants used positive opinions, feelings, or agreement, expressions of gratitude and appreciation and alerters most frequently of all. These findings are in line with Farnia and $\mathrm{Wu}$ (2012). Morkus (2009, p. 82) posited that adjuncts are "preliminary remarks that cannot stand alone and function as refusals". Taking into account Morkus' (2009) statement about adjuncts, one can assume that the use of them has been intended to serve the purposes of politeness. The following bold phrases are examples of adjuncts used by the participants:

- Mamnoon vali ba yeki az bacheha gharar daram.

- Thanks but I have to see a friend of mine. (Gratitude; Sit \#10; male EFL learner)

- $\quad$ Baese eftekhare bandast ke dar in jashn basham vali motaesefane bayad be ye mosaferate kuchik beram. Enshalla ye vaghte dige.

- It's an honour for me to be in your party but I'm afraid I have a little trip. Next time, God willing. (Positive feeling; Sit \#4; female EFL learner)

- Khob rastesh raiis man bayad beram ye jayi. Vaghean sharmandam. Enshalla dafeye ba'di.

- Well, boss, I have to go somewhere. I'm so sorry. God willing next time. (Pause filler; Sit \#4; male non-English learner) 


\section{Conclusion}

This study compared the use of refusal strategies by students of English and those of other majors in their L1 (i.e., Persian). The results revealed that both groups made use of specific refusal strategies such as "Non-performative statement", "Statement of regret", "Excuse, reason or explanation" and "Attempt to dissuade interlocutor". The EFL group used these refusal strategies less frequently than the non-English group did, although the former group used more adjuncts than did the latter group.

In general, the study findings suggest that there are differences between EFL and non-English learners in the use of refusal strategies and adjuncts to refusals. The differences are, however, more manifest in the number of the strategies, or the frequency with which these strategies have been employed, rather than in the types of the strategies. Furthermore, the results suggest that certain patterns of refusing are followed by both EFL and non-English learners, which might be indicative of the formulaic nature of the speech act of refusal. This conclusion might be tenable on the grounds that other speech acts, such as complimenting, have been found to be highly formulaic in nature (Johnson, 1992), a finding that can turn to be generalizable to refusal behavior as well.

\section{Implications of Study}

The findings of the current study imply that bidirectional influence of English on EFL learners' L1 use may not be at work at least in an EFL context such as Iran where English is a foreign language, if not in an English as a Second Language (ESL) one. In other words, regardless of the students' majors of study, in an L1, they would use the same, if not identical, strategies to refuse. Sociolinguistically speaking, then, it might be comforting for some to see that the cultural aspects of the English norms, which are viewed negatively by the majority of the authorities who regard these aspects as attempting to "westernize" Iranian society, as not influencing their L1 norms of language use because, in the end language is a social practice and indicative of one's identity (e.g., Fairclough, 1996; Norton \& McKinney, 2011).

\section{Limitations and Suggestions for Further Research}

This study was limited in some aspects. Further and future research can focus on these limitations in order to remedy and overcome them as doors for more research. One of the limitations relates to the use of a DCT to gather the data. Future research can benefit well from role plays as a more reliable data collection tool. On the plus side, studies with larger sample sizes are recommended. 
Finally, comparative studies examining the results of speech act strategy use by learners in their L1 and L2 would provide insights into the nature of the effect of exposure to an L2 on the L1.

\section{References}

Abdul Sattar, H. Q., Lah, S. C., \& Suleiman, R. R. R. (2011). Refusal strategies in English by Malay university students. GEMA Online ${ }^{\mathrm{Tw}}$ Journal of Language Studies, 11(3), 69-81.

Al-Kahtani, S. A. W. (2005). Refusals realizations in three different cultures: A speech act theoretically-based cross-cultural study. Journal of King Saud University, 18, 35-57.

Allami, H., \& Naeimi, A. (2011). A cross-linguistic study of refusals: An analysis of pragmatic competence development in Iranian EFL learners. Journal of Pragmatics, 43, 385-406.

Brown, P., \& Levinson, S. (1987). Politeness: Some Universals in Language Use. Cambridge: Cambridge University Press.

Ellis, R. (2012). The Study of Second Language Acquisition. USA: Oxford University Press.

Fairclough, N. (1996). Language and power. USA: Longman.

Farnia, M., \& Wu, X. (2012). An intercultural communication study of Chinese and Malaysian university students' refusal to invitation. International Journal of English Linguistics, 2(1), 162-176. Ghazanfari, M., Bonyadi, A., \& Malekzadeh, S. (2013). Investigating cross-linguistic differences in refusal speech act among native Persian and English speakers. International Journal of Research Studies in Language Learning, 2(4), 49-63.

Hassani, R., Mardani, M., \& Dastjerdi, H. V. (2011). A comparative study of refusals: Gender distinction and social status in focus. The International Journal - Language Society and Culture, 32. Retrieved 2013 from www.educ.utas.edu.au/users/tle/JOURNAL/ Johnson, D. M. (1992). Compliments and politeness in peer-review texts. Applied Linguistics, 13(1), 51-71.

Lingli, D., \& Wannaruk, A. (2010). The effects of explicit and implicit instruction in English refusals. Chinese Journal of Applied Linguistics, 33(3), 93-109.

Martínez-Flor, A., \& Usó-Juan, E. (2011). Research methodologies in pragmatics: Eliciting refusals to requests. $E L I A, 11,47-87$.

Morkus, N. (2009). The realization of the speech act of refusal in Egyptian Arabic by American learners of Arabic as a foreign language. Unpublished Doctoral Dissertation. University of South Florida, USA.

Nelson, G. L., Al Batal, M., \& El Bakary, W. (2002). Directness vs. indirectness: Egyptian Arabic and US English communication style. International Journal of Intercultural Relations, 26, 39-57.

Norton, B., \& McKinney, C. (2011). An identity approach to second language acquisition. In D. Atkinson (Ed.), Alternative Approaches to Second Language Acquisition (pp. 73-94). UK: Routledge. Silva, A. J. B. D. (2003). The effects of instruction on pragmatic development: Teaching polite refusals in English. Second Language Studies, 22(1), 55-106. 
Umale, J. (2011). Pragmatic failure in refusal strategies: British versus Omani interlocutors. Arab World English Journal, 2(1), 18-46.

Wannaruk, A. (2008). Pragmatic transfer in Thai EFL refusals. Regional Language Centre Journal, $39(3), 318-337$.

Yang, J. (2008). How to say 'no' in Chinese: A pragmatic study of refusal strategies in five TV series. Proceedings of the $20^{\text {th }}$ North American conference on Chinese linguistics, 2, 1041-1058.

\section{Biographical note}

Seyyed Hatam Tamimi SA'D, (b. 1989), MA in Applied Linguistics from Urmia University, Iran, is currently an English teacher in Iran Language Institute, Iran. A prolific researcher with many publications, he serves as a reviewer for nine international journals within applied linguistics. He has published with many journals and presented papers at different national and international conferences. His interest lies in acquisitional pragmatics, culture and ELT, learner attitudes, critical pedagogy and Computer-Assisted Language Learning.

Zohre QADERMAzI, MA in Applied Linguistics from Urmia University, Iran, is a prolific reseracher in the areas of English language teaching. She has published in many journals, has presented in a number of conferences and is at present a teacher of English in different language institutes. Her areas of interest include intercultural competence, culture in ELT and critical pedagogy. 


\section{Appendix 1}

\section{Refusal Discourse Completion Test (English Translation)}

\section{Instruction:}

Please read the following 12 situations. After each situation you will be asked to write a response in the blank after, you. Imagine that you do NOT want to comply (=agree) with their request, invitation, etc. Please respond as naturally as possible and try to write your response as you feel you would say it in the situation. The data will be used for research purposes only.

\section{Thanks wholeheartedly in advance!}

Age: ......

Major of Study: ......

\section{Situation 1}

You are the owner of a book store. One of your best workers asks to speak to you in private.

Worker: As you know, I've been here just a little over a year, and I know you've been pleased with my work. I really enjoy working here, but to be honest I really need an increase in pay.

You:

Worker: Well...then I guess I'll have to look for another job.

\section{Situation 2}

You are a junior in college. You attend classes regularly and take good notes. Your classmate often misses class and asks you for the lecture notes.

Classmate: Oh God. We have an exam tomorrow but I don't have notes from last week. I am sorry to ask you this, but could you please lend me your notes once again?

You:

Classmate: Well...then I guess I'll have to ask someone else.

\section{Situation 3}

You are the president of a big printing company. A salesman from a printing machine company invites you to one of the most expensive restaurants, Milad.

Salesman: We have met several times now, and I'm hoping you will buy 
my company's printing machine. Would you like to have dinner with me at Milad to sign the contract?

You:

Salesman: Well...maybe we can meet another time.

\section{Situation 4}

You are an executive at a very large software company. One day the boss calls you into his office.

Boss: Next Friday my wife and I are having a little party at my house. I know it's sudden...but I'm hoping all my executives will be there with their wives/husbands. Will you come to the party?

You:

Boss: Well...that's too bad. I was hoping everyone would be there.

\section{Situation 5}

You are at a friend's house watching TV. Your friend offers you a snack.

You: Thanks, but no, thanks. I've been eating like a pig and I feel just terrible. My clothes don't even fit me.

Friend: Hey, why don't you try this new diet I've been telling you about?

You:

Friend: Well...you should try it anyway.

\section{Situation 6}

Your boss just asked you to bring a report to him. You can't find the report on your desk because your desk is much disorganized. Your boss walks over.

Boss: You know, maybe you should try to organize yourself better. I always write things down on a piece of paper so I don't forget them. Why don't you try it?

You:

Boss: Well...it was only an idea anyway.

\section{Situation 7}

You arrive home and notice that your cleaning lady is extremely upset. She comes rushing up to you.

Cleaning lady: Oh God, I'm so sorry! I had a terrible accident. While I was cleaning, I bumped into the table and your china vase fell and broke. I feel very bad about it. I'll pay for it.

You (Knowing that the cleaning lady is supporting three children): 
Cleaning lady: No, I'd feel better if I paid for it.

\section{Situation 8}

You teach English at a university. It is just about the middle of the semester now. One of your students asks to speak to you.

Student: Ah, excuse me; some of the students were talking after class yesterday. We kind of feel that the class would be better if you could give us more practice in conversation and less on grammar.

You:

Student: Well...it was only a suggestion.

\section{Situation 9}

You are at a friend's house for lunch.

Friend: How about another piece of cake?

You:

Friend: Come on, just a little piece?

\section{Situation 10}

A friend invites you to dinner, but you really don't like this friend's husband/wife.

Friend: How about coming to my house Friday night? We're having a small dinner party.

You:

Friend: Well...maybe next time.

\section{Situation 11}

You have been working in an advertising company now for some time. The boss offers you an increase in salary and a better position, but you have to move to another city. You don't to go. Today, the boss calls you into his office.

Boss: I'd like to offer you an executive position in our new office in Shiraz. It's a great city, only 3 hours from here by airplane. And, your salary will increase with the new position.

You:

Boss: Well...maybe you should think about it some more before declining.

\section{Situation 12}

You are at the office in a meeting with your boss. It is getting close to the end of the day and you want to leave the office. 
Boss: If it's okay with you, I'd like you to spend an extra hour or two so that we can finish up with this work. Can you stay little longer at the office?

You:

Boss: Well, that's too bad...I was hoping you could stay. 